\title{
美丽中国建设时空演变及耦合研究
}

\author{
盖 美 ${ }^{1,2}$ * , 王秀琪 ${ }^{1,2}$ \\ 1 教育部人文社科重点研究基地,海洋经济与可持续发展研究中心, 大连 116029 \\ 2 辽宁师范大学海洋可持续发展研究院, 大连 116029
}

摘要:美丽中国是党的“十八大” 提出的新战略思想,也是生态文明建设发展的延续。本文以 2000-2017 年为研究时段,选取我 国 31 个省、市、自治区为研究区域,借助 GeoDa 空间自相关分析及动静态耦合模型,探索我国美丽中国建设的时空分异规律、空 间分布格局及系统耦合协调度。结果表明: (1)研究期内,我国美丽中国的发展呈波动上升趋势,且存在东部 >西部 $>$ 中部的空间 分布特征。(2)我国美丽中国的发展格局稳定,但东西部地区两极分化问题严重;子系统中,除制度体系不显著外,均存在显著正 向空间关联,且社会、经济、文化与环境高集聚区空间分布错位。(3)我国社会、环境、经济、文化、制度的静态耦合协调度呈波动 上升趋势, 东西部区域发展差异明显; 动态耦合不及静态耦合协调水平, 部分省市存在社会发展、绿色环境、经济增长、以及文化 和制度发展受阻现象。

关键词: 美丽中国;空间自相关;动静态耦合; 中国

\section{The temporal-spatial evolution and coupling of Beautiful China construction}

\author{
GAI Mei ${ }^{1,2, *}$, WANG Xiuqi ${ }^{1,2}$ \\ 1 Key Research Base of Humanities and Social Sciences of the Ministry of Education: Center for Studies of Marine Economy and Sustainable Development, \\ Dalian 116029, China \\ 2 Institute of Marine Sustainable Development, Liaoning Normal University, Dalian 116029, China
}

\begin{abstract}
Beautiful China is a new strategic thought presented by the 18th National Congress of the Communist Party of China, which is also the continuity of constructing ecological civilization. This paper aims to explore the law of temporalspatial differentiation, spatial distribution pattern and system coupling coordination degree of China's Beautiful China construction in 31provinces, municipalities, autonomous regions from 2000 to 2017 on the basis of GeoDa spatial autocorrelation analysis and dynamic coupling model. The results showed that (1) the development fluctuation of China's Beautiful China was on the rise with spatial distribution characteristics of eastern $>$ western $>$ central area. (2) On the whole, the development pattern of Beautiful China is stable. But the eastern and western regions are deeply polarized. In the Beautiful China subsystem, except the spatial autocorrelation of the system subsystem is not significant, there are significantly positively spatial correlations in other systems. And the spatial distribution of social, economic, cultural and environmental high-agglomeration areas is dislocated. (3) China's social, environmental, economic, cultural and institutional static coupling coordination degree is fluctuating upward trend with significant difference of regional development between east and west regions. The dynamic coupling is less than static coupling coordination. The social development, green environment, economic growth, and cultural and institutional development are still hindered in some provinces and cities.
\end{abstract}

Key Words: Beautiful China; spatial autocorrelation analysis; dynamic coupling and static coupling; China

基金项目: 国家社会科学基金重大项目(14ZDB130)

收稿日期:2020-06-30; 修订日期:2020-11-02

*通讯作者 Corresponding author.E-mail: gaimei71@163.com 
美丽中国是党在 “十八大” 时首次提出的概念, 是生态文明建设的奋斗目标 ${ }^{[1]}$ 。自党在 “十七大” 报告中 首次提出生态文明建设理念后,我国能源资源节约开发,生态环境得到明显改善,因此,党的“十八大” 继续推 进生态文明建设,提出“将生态文明建设放在突出地位, 融人到经济建设、政治建设、文化建设、社会建设各方

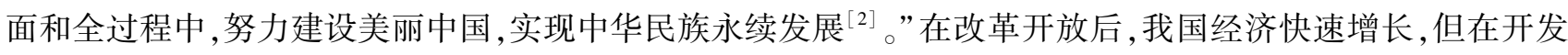
中忽视了环境保护和资源的合理利用,导致我国资源浪费、环境污染、生态系统退化严重。因此,建设美丽中 国并探究其演变及系统协调变化是为生态文明体制改革以及可持续发展道路提供新路径, 同时也为我国未来 的发展方向提供参考。

美丽中国作为我国重要的战略思想, 已成为社会各界及学术界关注的焦点,有关美丽中国的内涵, 不同学 者有着不同的阐述 ${ }^{[3-6]}$ 。目前,国外学者对 “美丽中国” 的研究较少 ${ }^{[7]}$,多为对可持续发展层面的分析 ${ }^{[8-9]}$, 国 内学者们对美丽中国的研究主要集中在指标选取、协调性以及研究路径等方面。(1) 指标体系构建方面: 早 期学者如时朋飞等从美丽环境、美丽经济、美丽生活生态位三方面构建美丽中国生态位评价体系 ${ }^{[10]}$, 向云波 等从资源生态、经济发展、社会伦理、文化政治四个维度, 20 个单项指标构建美丽中国区域建设的评价模 型 ${ }^{[11]}$, 近年来, 学者们如方创琳 ${ }^{[12]}$ 、高卿 ${ }^{[13]}$ 等参考生态文明建设目标, 从 “五位一体” 的角度构建美丽中国评 价指标体系。(2) 协调性方面: 目前, 对美丽中国协调性研究较少, 部分学者采用静态耦合分析其协调性, 且 多关注美丽中国与区域旅游化 ${ }^{[14-15]}$ 、新能源汽车产业 ${ }^{[16]}$ 、科技创新 ${ }^{[17]}$ 等外部因素的耦合协调, 而对系统内部 协调的研究仅有谢炳庚从环境一经济一社会文化方面, 对江西省的美丽中国建设构建耦合协调模型 ${ }^{[18]}$, 未探 讨系统间的动态变化, 缺乏对系统方向变化的探究。(3) 研究内容方面: 目前, 多数学者选择对美丽中国建设 的研究理论 ${ }^{[19]}$, 以及在其他视角下对美丽中国 ${ }^{[20-21]}$ 或在美丽中国视阈下对某一方面进行研究 ${ }^{[22-23]}$, 如刘笑 菊基于 “美丽中国” 建设视角对当代大学生生态素养的培育以及传承传统生态文化进行讨论 ${ }^{[24]}$, 也有少量学 者对美丽中国理论进行评价分析 ${ }^{[12.25]}$, 如谢炳庚采用主成分分析法对湖南省的美丽中国建设发展进行 分析 ${ }^{[26]}$ 。

综上所述,学者们围绕美丽中国建设的指标体系、协调性和研究路径等方面进行了较详细的理论分析和 实践,但仍存在问题。(1) 完善美丽中国建设评价体系。在已有评价指标中,存在二级指标分类不清或含义 相近的情况, 因此, 本文在借鉴已有评价指标的基础上, 从生态角度出发, 整合含义相近的指标, 如将自然保护 区及森林草原面积整合为生态面积, 并添加具有生态代表性的指标加人到各系统中, 如生活用电量、公众参与 度等, 最终划分为社会发展、绿色发展、经济增长、文化传承以及制度体系五方面。(2)研究仅限于静态耦合 分析。美丽中国建设是一个动态概念, 有着动态的演变过程, 但现有文献多为对要素起止时间点的状态值的 研究, 即静态耦合协调, 并未考虑到观测始末时间点的变化状态, 即未考虑观测期内系统间动态变化的大小与 方向。(3)丰富研究内容。在已有研究中, 学者们的研究多数停留在对美丽中国的理论研究或评价层面, 缺 乏对美丽中国建设进一步的系统研究。因此本文在评价美丽中国建设的基础上, 借助 GeoDa 软件对我国各 省市在研究期内美丽中国建设及其子系统的时空分布格局进行分析, 并在此基础上, 进一步采用动静态耦合 协调模型,分析我国美丽中国建设系统间相互协调关系,为今后发展美丽中国建设提供现实参考依据。

\section{1 评价模型构建与研究方法}

\section{1 机理研究}

根据已有的美丽中国内涵, 由社会、经济、环境、文化以及制度共同构成。这些子系统在美丽中国建设中 的作用是相互的, 其中最重要的是环境。环境主要体现在环境容量及资源承载力方面, 主要包括环境质量、污 染处理等方面,过多的人类活动会导致环境恶化, 其结果直接反馈于人类生产和生活环境, 进而影响社会经济 的发展; 经济增长离不开资源的开发利用, 因此优化绿色产业, 发展生态经济, 推动地区特色产业, 是建设绿色 经济的重要途径; 社会发展的前提是尊重自然、保护自然,其立足之本为经济建设,同时需文化积累作为发展 
的催化剂; 文化作为社会发展的意识形态, 体现在当地居民的教育程度和基本素质上,直接影响了当地经济的 增收或消减,而文化通常与制度并存,二者相辅相成,共同促进美丽中国建设协调发展; 制度作为美丽中国建 设发展的保障, 为经济和社会提供了发展基础,在经济、社会以及环境三者之间起到了促进、调节和约束的作 用。综合来看,环境是基础,经济是动力,社会是前提, 文化是后盾,制度是保障,五者协同一致,共同促进美丽 中国建设的发展。

\section{2 指标体系构建与数据来源}

根据美丽中国 “五位一体”总布局的内涵,参考党的“十八大”、“十九大”报告原文、现有研究成果 ${ }^{[7-10]}$ 及 国家“美丽中国”评价指标体系等, 重新归纳总结, 将生态理念融人指标体系中并选取代表性指标, 构建社会 发展、绿色环境、经济增长、文化传承、制度体系五个指标体系 (图 1)。其中,社会发展涉及区域城镇化、人口、 基础设施建设、医疗等方面, 可以系统的体现出地区居民生活、消费以及基础设施建设等方面; 绿色环境主要 体现区域发展对当地生态环境的影响,包括空气质量、环保投人、污染物排放及处理情况等指标; 经济增长涵 盖经济发展、产业结构等方面,鉴于美丽中国建设需要统筹兼顾经济发展的速度和环境保护的质量, 加人可以 代表经济发展消耗资源现状的单位GDP 水耗和能耗; 文化传承代表区域的文明发展情况,因此选取文化产物 以及地区教育现状; 制度体系为地区法律建设的体现, 有效的政策支持以及公众参与, 可以更好地加快美丽中 国的建设。

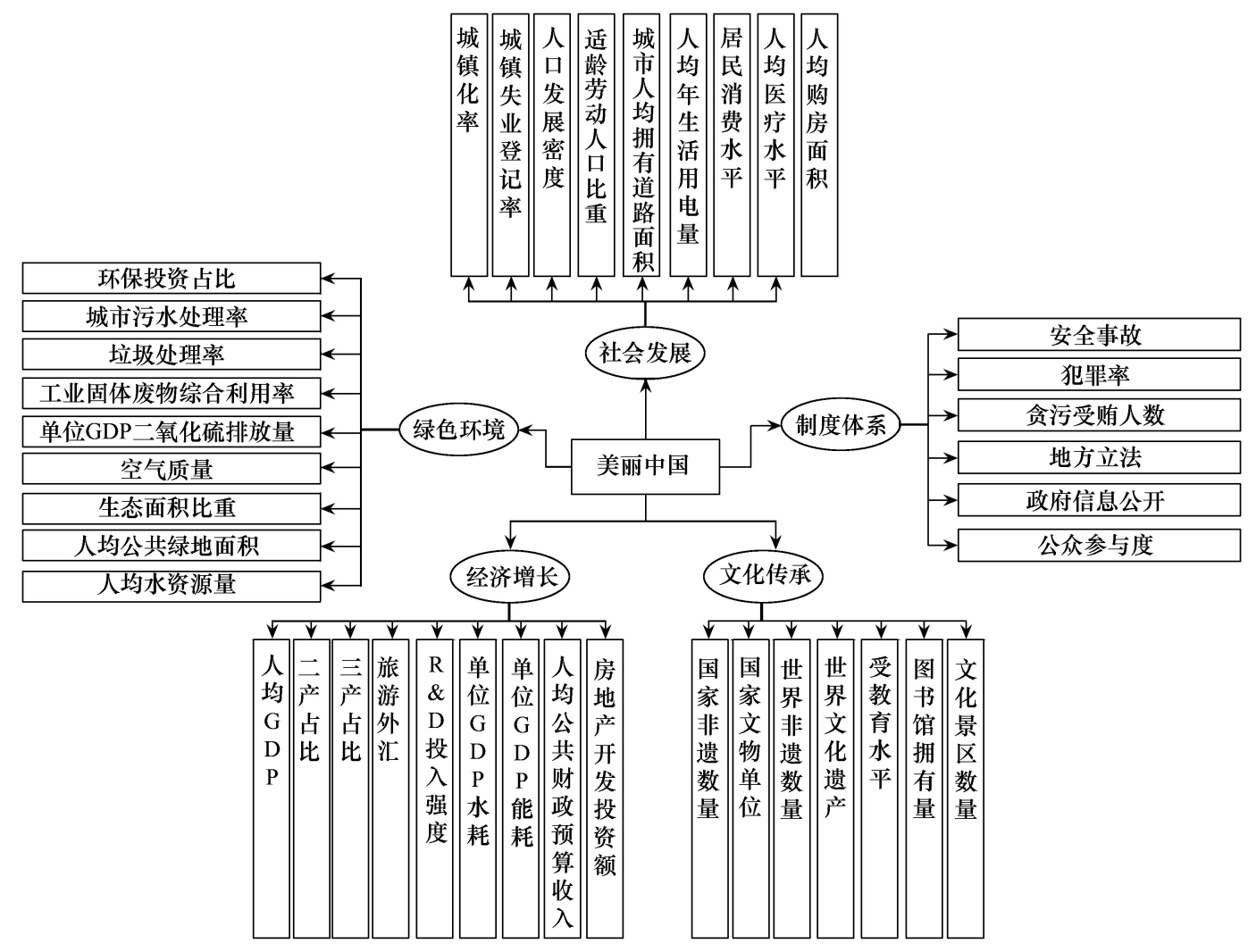

图 1 美丽中国建设评价指标体系

Fig.1 Evaluation index system of Beautiful China construction

本文选取除我国港、澳、台地区以外的其它 31 个省、市、自治区 2000-2017 年的数据,数据来源自各地

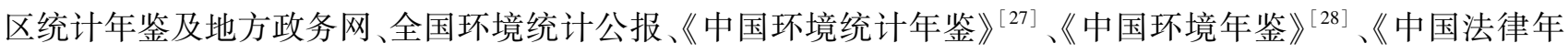
鉴》 ${ }^{[29]}$ 及《中国检查年鉴》 ${ }^{[30]}$ 等。其中, 人口发展密度是指区域人口数与土地面积的比值; 适龄劳动人口比重 为 15-64 岁人口占总人口的比重; 生态面积比重指地方自然环境保护区占辖区总面积的比重; 受教育水平指 
一个地区的平均受教育年限;政府信息公开选取政府发布有关生态保护的政策数量;公众参与度选取地区检 举揭发数、信访人数占总人口比重。

\section{3 研究方法}

\subsection{1 评价方法}

本文参考国内学者关于美丽中国建设评价体系的分析研究 ${ }^{[12]}$, 结合实际情况,采用改进的熵权 Topsis 法 $^{[31-32]}$, 进行主观 ${ }^{[33]}$ 和客观相结合的赋权法, 计算得到美丽中国发展指数 (简称发展指数) (I) 及子系统指数 $(S 、 E 、 G 、 L 、 H)$ 更具合理性和科学性。

\subsection{2 核密度估计法}

核密度估计是一种非参数的表面密度计算方法,需要通过输人的要素数据集获得整个区域的数据集聚情 况,可以清晰的反应区域要素在空间上的局部密度变化以及空间分布的热点区域 ${ }^{[34]}$ 。其公式如下:

$$
f_{n}=\frac{1}{n h} \sum_{i=1}^{n} k\left(\frac{x-x_{i}}{h}\right)
$$

其中: $f_{n}$ 为核密度估计值; $n$ 为省 (市、自治区) 总数; $x_{1}, x_{2}, \ldots, x_{n}$ 是从分布密度函数 $(f)$ 的总体中抽取的省发展 指数; $\left(x-x_{i}\right)$ 为估计点 ${ }^{x}$ 到样本点 $x_{i}$ 的距离; $h$ 为搜索半径。

\subsection{3 空间自相关分析}

空间自相关分析法分为全局空间自相关和局部空间自相关 ${ }^{[35-36]}$ 。全局空间自相关采用 Moran's $I$ 进行分 析, 但因忽视了空间过程潜在的不稳定性, 因此采用局域空间自相关来分析具体空间的集聚状态和位置, 计算 公式如下:

全局空间自相关:

局部空间自相关:

$$
\operatorname{Moran}^{\prime} s I=\frac{n \sum_{i=1}^{n} \sum_{j=1}^{n} w_{i j}\left(x_{i}-\bar{x}\right)}{\sum_{i=1}^{n} \sum_{j=1}^{n} w_{i j} \sum_{i=1}^{n}\left(x_{i}-\bar{x}\right)^{2}}
$$

$$
\text { Moran's } I_{i}=\frac{n\left(x_{i}-\bar{x}\right)}{\sum_{i=1}^{n}\left(x_{i}-\bar{x}\right)^{2}} \sum_{j=1}^{n} w_{i j}\left(x_{j}-\bar{x}\right)
$$

其中: $n$ 为省 (市、自治区) 总数; $x_{i}$ 和 $x_{j}$ 分别为省及省发展指数; $\bar{x}$ 为变量 $x$ 的均值; $W_{i j}$ 代表空间权重矩阵。 Moran's $I$ 接近 0 , 表明 $i$ 省的发展指数与相邻地区的空间自相关越弱; Moran's $I$ 接近 1 或 -1 , 表明 $i$ 省的发展 指数与相邻地区的空间自相关越强或集聚性越强。Moran's $I_{i}>0$, 说明该省与相邻地区有类似的高值或低值, 空间集群为 HH 集群 (即高值区相邻) 和 LL 集群(即低值区相邻); Moran's $I_{i}<0$, 说明该省的取值与相邻地区 的取值有显著差异, 即空间离群, 分为 HL 集群( 高值区与低值区相邻), 和 LH 集群 ( 低取值区与高取值区相 邻)。

\subsection{4 耦合协调度模型构建}

物理学中通常采用耦合函数进行定量测度 ${ }^{[37]}$, 借用耦合协调模型可以有效的揭示我国美丽中国建设发 展过程中社会、环境、经济、文化以及制度的现状和内在协调关系,但美丽中国的发展是动态演变过程,需考虑 到系统动态变化的大小与方向。因此本文将建立动静态结合的方法, 首次采用五元耦合, 监测研究期间我国 美丽中国建设发展的耦合协调程度。由于动态耦合存在负值情况, 仅研究到耦合度,计算公式如下:

静态耦合协调度:

$$
C_{i}=\left\{\frac{S_{i} \times E_{i} \times G_{i} \times L_{i} \times H_{i}}{\left(\frac{S_{i} \times E_{i} \times G_{i} \times L_{i} \times H_{i}}{5}\right)^{5}}\right\}^{\frac{1}{5}}
$$


动态耦合度：

$$
D=\sqrt{C_{i} T}, T=\alpha_{1} S+\alpha_{2} E+\alpha_{3} G+\alpha_{4} L+\alpha_{5} H
$$

$$
\begin{gathered}
D C_{i}=\left\{\frac{\Delta S_{i} \times \Delta E_{i} \times \Delta G_{i} \times \Delta L_{i} \times \Delta H_{i}}{\left(\frac{\left|\Delta S_{i}\right| \times\left|\Delta E_{i}\right| \times\left|\Delta G_{i}\right| \times\left|\Delta L_{i}\right| \times\left|\Delta H_{i}\right|}{5}\right)^{5}}\right\}^{\frac{1}{5}} \\
\Delta S_{i}=\frac{S_{i}^{t_{2}}-S_{i}^{t_{1}}}{S_{i}^{t_{1}}} ; \Delta E_{i}=\frac{E_{i}^{t_{2}}-E_{i}^{t_{1}}}{E_{i}^{t_{1}}} ; \Delta G_{i}=\frac{G_{i}^{t_{2}}-G_{i}^{t_{1}}}{G_{i}^{t_{1}}} ; \Delta L_{i}=\frac{L_{i}^{t_{2}}-L_{i}^{t_{1}}}{L_{i}^{t_{1}}} ; \Delta H_{i}=\frac{H_{i}^{t_{2}}-H_{i}^{t_{1}}}{H_{i}^{t_{1}}}
\end{gathered}
$$

其中: $S_{i} 、 E_{i} 、 G_{i} 、 L_{i} 、 H_{i}$ 分别代表社会发展、绿色环境、经济建设、文化传承以及制度体系的发展值; $t_{1} 、 t_{2}$ 为研究 时段始末时间点; $\Delta S_{i} 、 \Delta E_{i} 、 \Delta G_{i} 、 \Delta L_{i} 、 \Delta H_{i}$ 分别表示 $i$ 地区各系统的变化率; $\left|\Delta S_{i}\right| 、\left|\Delta E_{i}\right| 、\left|\Delta G_{i}\right| 、\left|\Delta L_{i}\right| 、\left|\Delta H_{i}\right|$ 为 系统绝对值; $C_{i}$ 为静态耦合度,于 $(0,1)$ 间取值; $T$ 代表美丽中国建设系统的综合调和指数; $\alpha_{1}-\alpha_{2}$ 代表各子系 统的贡献值, 因各子系统作用相同, 均取 $0.2 ; D C_{i}$ 为动态耦合度, 于 $(-1,1)$ 间取值, $D C_{i}<0$ 代表系统中存在一 个、三个或五个负增长现象,正值表明各系统中五个均为正增长或两个、四个出现负增长。本文采用“十分 法”评价等级标准 ${ }^{[38-39]}$ 对美丽中国建设耦合协调度 $(D)$ 进行划分。

\section{2 我国美丽中国建设时空格局分析}

\section{1 我国美丽中国建设时间特征分析}

根据 2000-2017 年数据计算出我国发展指数 ( 图 2), 2000-2017 年我国发展指数从 12.51 波动上升至 14.02 ,年均增长率为 $8.88 \%$ 。可分为三个阶段: (1)增速 阶段 (2000-2006 年), 发展指数年均上升率为 $13.28 \%$, 该阶段处于 “十五” 时期,美丽中国理念尚未提出,我国 正处在经济的快速发展阶段,环境污染和资源浪费的现 状较重; (2)转型阶段 (2007-2012 年), 我国发展指数增 长幅度下降至 $10.5 \%$, 该阶段处于生态文明建设理念首 次提出的 “十七大” 时期,我国基本形成节约资源、能源 以及生态环境保护的经济增长和消费模式,但受 2008 年金融危机的冲击, 我国经济增速略有下降; (3)发展稳 定阶段 (2013-2017 年), 发展指数年增长率仅有 $4.75 \%$, 该阶段处于 “十八大”美丽中国建设提出时期， 强调环境保护和经济高质量共同发展的模式。

本文进一步选取 2000 、2008 及 2017 三个年份的核 密度图, 对美丽中国建设发展进行分析(图 3)。从位置 上看, 3 个年份的核密度分布曲线呈向右平移的态势, 但 2017 年右移幅度明显缩小, 说明美丽中国建设的发 展速度由快到慢, 逐步趋于平稳。从峰度上看, 美丽中 国的发展水平在三年中均呈宽峰分布, 2000 年峰值明 显低于 2008 及 2017 年, 且呈现明显的“双峰”特征, 这 说明 2000 年时各省市的发展水平存在“两极分化”, 且 低值区的峰值略弱于高值区的峰值, 表明此时少数省市 的发展程度不高, 大部分省市处于较高水平。随着时间的增长,高水平省市总体水平略有提升,低水平省市发 展迅速, 使得两级分散的趋势逐渐弱化并逐步趋于合并,2017 年的峰值与 2008 年相比有微弱降低, 发展速度

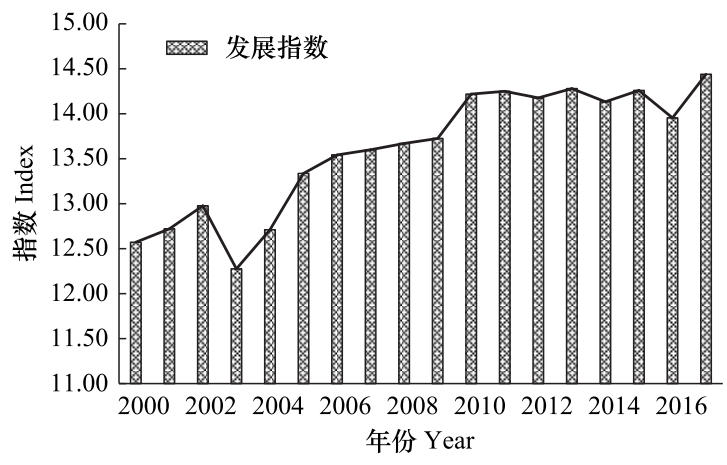

图 2 美丽中国建设时间特征图

Fig.2 Time characteristics of Beautiful China

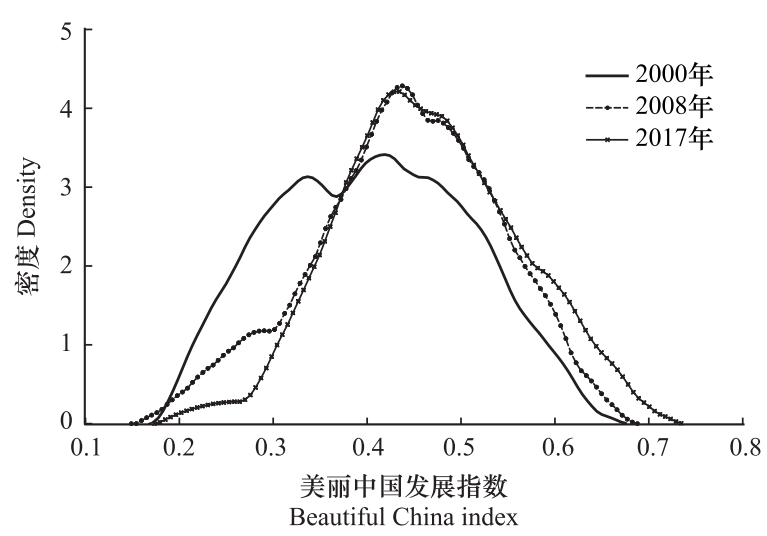

图 3 美丽中国建设核密度图

Fig.3 The nuclear density map of Beautiful China 
减缓,这也同上文分析一致,表明我国开始注重质量型而非速度型发展。

\section{2 我国美丽中国建设空间特征分析}

比较我国各省市发展指数演变 (图 4), 可以看出我国各省美丽中国建设发展存在显著差异 (以下采用省 份简称代替省级行政单位全称)。2000 年时沪、云、粤等地美丽中国发展水平明显高于其他省市,空间分布不 明显,2008 年美丽中国建设发达省市 $(I>0.5)$ 明显多于 2000 年,新增闽、京及浙,且在发展较好的省市中,东 部为占比较大地区,2017 年时,美丽中国发展程度较高的集聚区集中在粤、闽、沪、云、京、赣、浙、苏等东南沿 海区, 其中发展程度较好的省市为沪、粤, 而宁夏常年干旱, 水资源严重缺乏等情况一直为发展程度最差的省 份。从 2000 到 2017 年间,大部分省市符合美丽中国建设总体发展特征, 呈上升型省市; 津、桂、云、宁为美丽 中国建设发展平稳型省市; 沪、琼、新为波动型省市, 其中新疆的发展指数波动程度较大, 究其原因为其社会、 经济发展较不稳定, 且粗放式经济发展加重了资源环境的压力; 仅吉林为下降型省份,该地近年的经济及城市 化进程发展速度加快, 造成当地煤烟污染严重, 绿色环境严重下滑, 导致其发展指数从 0.47 下降到 0.37 。
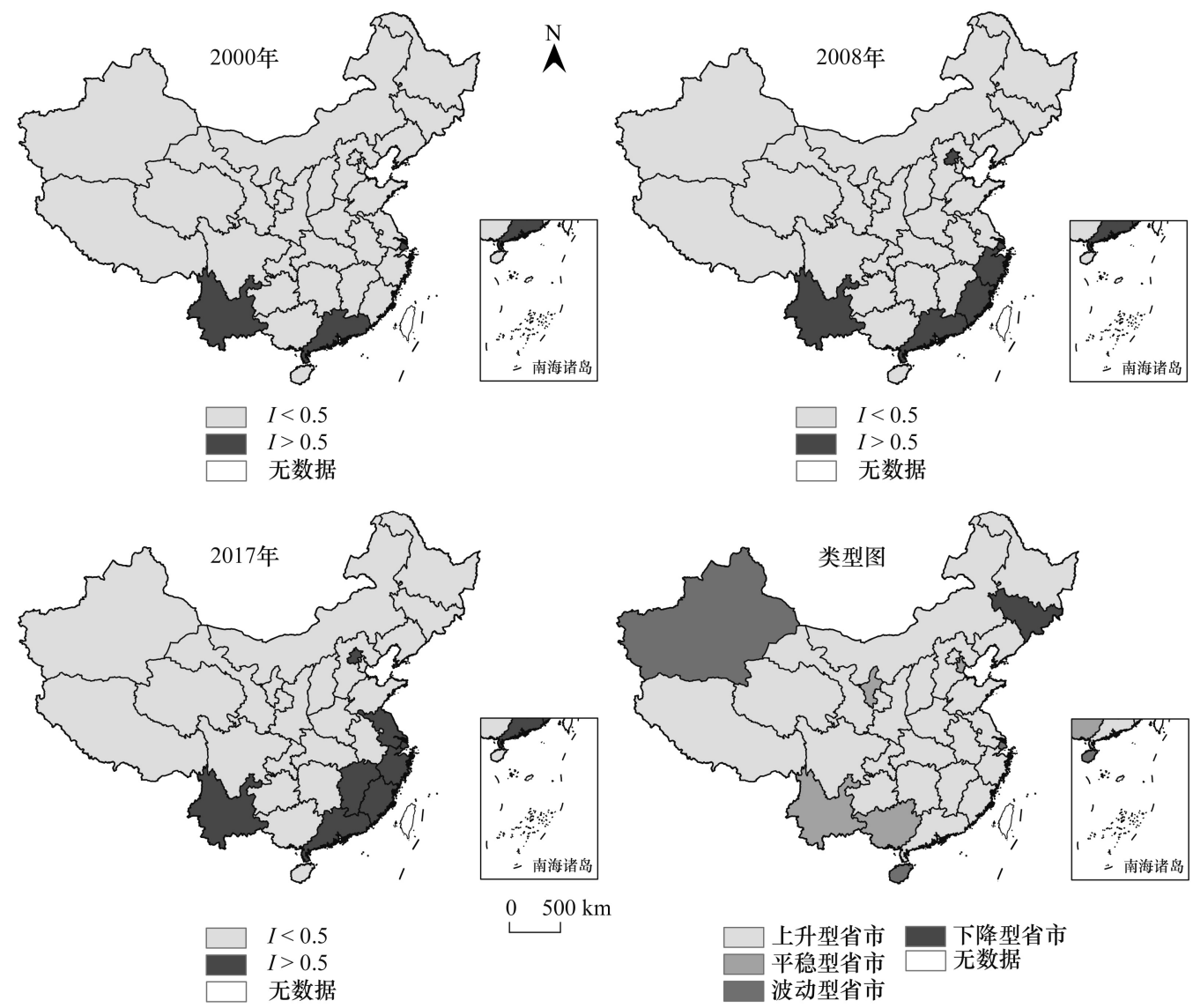

图 4 美丽中国建设空间分布图

Fig.4 Spatial distribution of Beautiful China construction

\subsection{1 全局空间自相关结果分析}

本文进一步利用全局空间自相关系数研究我国各省市美丽中国建设发展的相关性(图 5 )。从图 5 可知, 2000-2017 年发展指数及其子系统中,除制度体系未通过显著性检验,没有明显的空间集聚特征,其余系统 的 Moran's I 指数值介于 $0.120-0.547$ 之间, 且均显著为正, 同时 $P$ 值均小于 0.05 , 表明我国美丽中国的发展一 直存在显著的正向空间关联特征, 即发展指数及子系统值高的地区与其他指数值高的地区相邻, 指数低的地 区与指数低的地区相邻。发展指数及其子系统均呈现出波动上升的趋势, 说明我国美丽中国建设发展的空间 集聚态势逐渐增强, 同时发展状态也呈向好的趋势, 完成了从只索取利用自然资源环境到人与自然和谐相处 
的转变,社会发展进步迅速, 人均 GDP 增长 7 倍,环境问题得到较大幅度改善, 人民生活质量及文化素养水平 得到提升,但仍存在政策滞后性严重、生态环境污染、资源浪费、区域经济发展差距较大等问题。

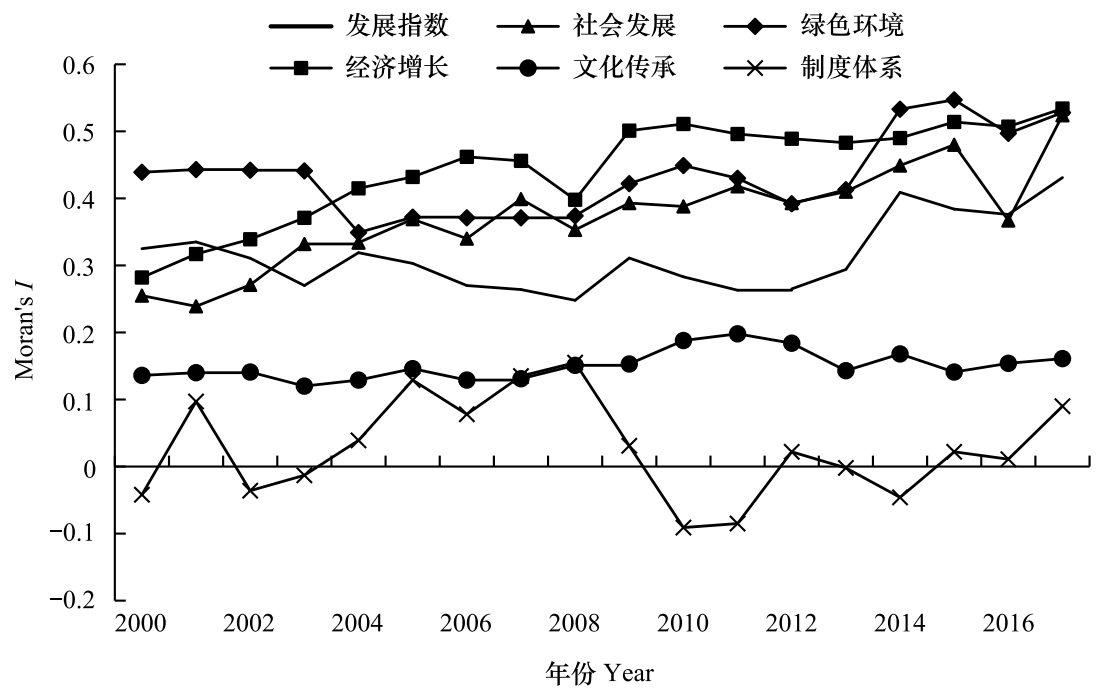

图 $52000-2017$ 年我国美丽中国建设 Moran's $I$ 指数折线图

Fig.5 Moran's $I$ index line chart of Beautiful China construction of China from 2000 to 2017

\subsection{2 局部空间自相关结果分析}

为进一步研究各省市美丽中国建设的局部空间相关性,利用 GeoDa 软件将我国发展指数划分为四种类 型(表 1)：

表 $12000-2017$ 年我国美丽中国建设发展指数象限分类

Table 1 Quadrant classification of Beautiful China construction and development index in 2000—2017

\begin{tabular}{|c|c|c|c|c|}
\hline $\begin{array}{l}\text { 年份/地区 } \\
\text { Year/Region }\end{array}$ & $\mathrm{HH}$ & HL & LL & LH \\
\hline 2000 & $\begin{array}{l}\text { 津、苏、沪、浙、闽、粤、桂、云、琼、 } \\
\text { 新、藏 }\end{array}$ & 吉、辽、京、赣 & $\begin{array}{l}\text { 冀、豫、鄂、鲁、秦、内蒙古、渝、 } \\
\text { 晋、晥、湘、黔、川、甘、宁 }\end{array}$ & 黑、青 \\
\hline 2008 & $\begin{array}{l}\text { 闽、琼、津、苏、沪、浙、粤、桂、云、 } \\
\text { 藏、新 }\end{array}$ & 吉、辽、京、赣 & $\begin{array}{l}\text { 内蒙古、秦、渝、冀、晋、鲁、豫、 } \\
\text { 晥、川、甘、宁、鄂、黔、湘 }\end{array}$ & 黑、青 \\
\hline 2017 & $\begin{array}{l}\text { 浙、闽、苏、沪、粤、鲁、桂、琼、云、 } \\
\text { 藏、新、青 }\end{array}$ & 贑、京、辽、黑 & $\begin{array}{l}\text { 内蒙古、宁、秦、晋、豫、渝、冀、 } \\
\text { 晥、津、鄂、湘、川、吉、甘 }\end{array}$ & 黔 \\
\hline
\end{tabular}

HH: 高值区相邻 High-High; HL: 高值区与低值区相邻 High-Low ; LL: 低值区相邻 Low-Low; LH : 低值区与高值区相邻 Low-High

从数量上看, $\mathrm{HH}$ 集群以及 LL 集群的数量基本相当, 即高水平类型以及低水平类型的省市空间集聚明 显, 而 LH 区 (本省为低水平类型省市而邻省为高水平类型省市) 及 HL 区 (本省为高水平类型省市而邻省为 低水平类型省市) 较少, 说明我国美丽中国建设发展空间格局基本稳定,但两极分化严重, HH 集群数量从 2000 、2008 的 11 个增加到 2017 年的 12 个, LL 集群数量则从 2000 年 14 个降到 2017 年 13 个,这表明 $2000-$ 2017 年我国美丽中国发展较好的省市空间集聚程度基本未变,发展较差的省市集聚程度略有减轻; 从空间动 态分布来看,发展较差的省市大部分集中在中西部地区, 发展较好的省市基本分布在我国东南沿海以及西部 边界地区,且随着时间增长,有向中部地区扩散的趋势。

2000 年我国美丽中国建设发展以 HH 以及 LL 集聚为主,黑、青两个省份处于 LH 集群,即两地发展指数 较低, 而相邻省域的发展指数相对较高, 其中黑龙江作为我国重工业基地, 内部经济结构发展不平衡, 以重工 业为主, 经济发展相对缓慢, 且长期发展高耗能、高污染的产业加剧了环境污染问题。2017 年, 我国美丽中国 建设发展仍以 HH 及 LL 集聚为主。在 12 个 HH 集群中, 琼、云、新、桂、藏、青是以绿色环境为主导的美丽中 
国发展省份,且大部分位于西南地区,该地区拥有全国 70\% 的水资源,为当地经济、社会发展提供了必要条 件,同时也是文化旅游资源丰富地区; 浙、闽、苏、沪、粤、鲁等东南沿海区,包括了我国两大经济带一一长三角、 珠三角, 经济发展吸引了大量的人才, 带动当地社会进步, 因此社会经济发展成为其美丽中国建设发展的重要 途径。处于 LL 集群的省市大部分位于中西部地区,这些省市经济水平一般, 人才流失严重, 且存在环境污染 问题,因此美丽中国建设发展落后。

值得注意的是,天津在 2000 及 2008 年时为 HH 集聚区,但在 2017 年转为 LL 集聚区。天津市是我国四 大直辖市之一, 该地人均 GDP 总值虽一直领先于全国大部分地区, 但经济增长率却下滑严重, 从 2000 年 $12.6 \%$ 下滑到 2017 年仅 $3.3 \%$, 同时天津市注重大型石油化工产业,产业结构固化, 未能及时转型, 随着生态环 境污染日益严峻,执法力度增强, 其石油产业发展受到限制, 天津市发展水平日渐落后; 黑龙江在 2000 年为 LH 集群区, 在 2017 年时转变为 HL 集群区, 即从低发展指数省转变为高发展指数省,近年来该地加快产业结 构转型,产业比重从 2000 年的 12.16:54.95:32.89 调整至 2017 年 18.65:25.53:55.82, 实现了产业结构由 “二三 一” 向“三二一”的转变, 同时加大了环境治理力度, 单位 GDP 二氧化硫排放量从 2000 年 $94 \mathrm{t} /$ 万元降到 2017 年 $18.47 \mathrm{t} /$ 万元,进一步改善了生态环境, 提高了当地美丽中国的发展状况。

利用 Geoda 软件计算出各子系统 2017 年局部 Moran's I 指数散点图 (图 6), 从构成看, 子系统的空间分布
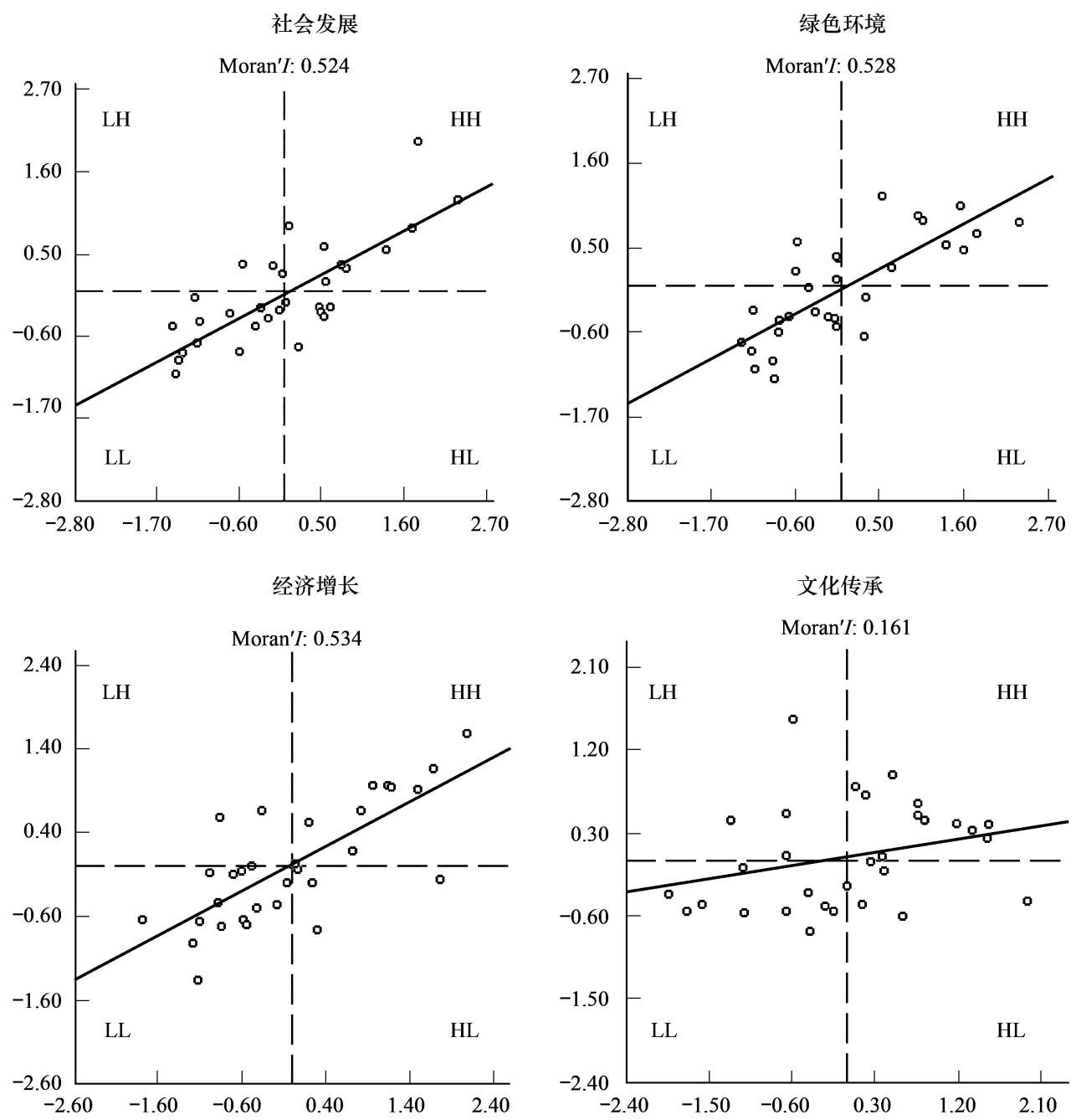

图 62017 年我国美丽中国建设系统构成指数 Moran's I 指数散点图

Fig.6 Scatter diagram of Moran's $I$ index of Beautiful China construction system in 2017

HH : 高值区相邻 High-High; HL: 高值区与低值区相邻 High-Low ; LL : 低值区相邻 Low-Low ; LH: 低值区与高值区相邻 Low-High 
格局主要集中在 HH 及 LL 集群。(1)2017 年社会发展 HH 集聚区主要为京、津、沪、鲁、苏、浙、粤、闽、琼等 9 个 省市, LL 集聚区主要为黑、吉、内蒙古、晋、湘、云、黔、桂、秦、青、新、藏、甘、宁等 14 个省。(2)绿色环境 HH 集 聚区分布在藏、新、青、赣、闽、云、桂、粤、琼等 9 个地区, LL 集聚区分布在宁、甘、秦、晋、鲁、豫、苏、晥、鄂、渝、 辽、津、冀、京等 14 个地区。(3)经济增长 HH 集聚区分布在鲁、苏、晥、浙、沪、闽、粤、津、冀、京等 10 个省市, LL 集聚区在黑、吉、辽、晋、秦、宁、甘、内蒙古、新、青、藏、云、黔、桂等 14 个省市。(4)文化传承 HH 集聚区为藏、 晋、秦、内蒙古、鲁、豫、苏、晥、鄂、浙、冀、京等 12 个地区、LL 集聚区为黑、宁、甘、湘、云、黔、桂、琼、吉、川等 10 个地区。由于制度体系不具有显著性分布, 因此无法探求其分布规律。综上可知,社会发展、经济增长及文化 传承的 HH 集聚区基本集中在东南沿海地区,LL 集聚区则集中在我国中西部及东北地区,绿色环境 HH 集聚 区在部分中西部区分布, LL 集聚区则集中在我国中东部地区,此空间分布情况在一定程度上反映了我国东部 地区尤其是东南部地区拥有较高的社会、经济、文化发展水平,但社会经济的发展需要资源环境作为基础, 因 此对环境承载力有一定程度的损耗, 给资源环境带来巨大的压力大; 中西部地区相较于东部地区而言发展相 对落后,除环境外,均为我国中西部地区发展的制约条件。

\section{3 我国美丽中国建设系统耦合协调分析}

根据上文可知, 我国美丽中国建设区域发展不平衡,因此为进一步探求社会发展、经济增长、绿色环境、文 化传承以及制度体系五个系统间协调发展程度, 将采用动静态耦合协调法对我国美丽中国建设发展进行 讨论。

\section{1 静态耦合协调}

从表 2 可知,在 2000-2017 年间,美丽中国建设系统间静态耦合协调度介于 $0.443-0.753$ 之间,从数值 看,美丽中国建设系统耦合协调度从 2000 年到 2017 年处于波动上升趋势,协调等级从 2000-2003 年濒临失 调到 2004 年的基本协调, 再到 2005-2012 年的初级协调,最终在 2013-2017 年间达到中级协调, 表明我国 美丽中国的发展仍有巨大的提升空间,且五个系统间仍需较长时间进行磨合, 这主要是因为我国处于转型期, 即新旧动能转换期以及发展阶段转换期，环境同经济、社会、文化、制度的协同发展仍存在结构及体制性问题。

表 22000 -2017 年美丽中国建设动静态耦合协调度

Table 2 Static and dynamic coupling degree of Beautiful China construction from 2000 to 2017

\begin{tabular}{lccccccccc}
\hline 年份 Year & 2000 & 2001 & 2002 & 2003 & 2004 & 2005 & 2006 & 2007 & 2008 \\
\hline $\begin{array}{l}\text { 静态塊合协调度 } \\
\begin{array}{l}\text { Static coupling degree } \\
\text { of coordination }\end{array}\end{array}$ & 0.443 & 0.457 & 0.461 & 0.446 & 0.518 & 0.602 & 0.626 & 0.647 & 0.670 \\
\hline \hline 年份 Year & 2009 & 2010 & 2011 & 2012 & 2013 & 2014 & 2015 & 2016 & 2017 \\
\hline $\begin{array}{l}\text { 静态耦合协调度 } \\
\begin{array}{l}\text { Static coupling degree } \\
\text { of coordination }\end{array}\end{array}$ & 0.671 & 0.691 & 0.688 & 0.678 & 0.707 & 0.714 & 0.724 & 0.748 & 0.753 \\
\hline
\end{tabular}

因此,选取 2000、2008、2017 年三年的耦合协调度状况进行分析 (图 7)。我国美丽中国建设系统间耦合 协调类型变化主要为: 2000 年时五个系统之间以失调为主, 但到 2017 年时已经转变为协调, 其中严重失调及 中度失调的地区在 2008 年消失, 轻度及濒临失调地区从 2000 年 12 个增加到 2008 年 19 个并在 2017 年消失, 基本协调及初级协调地区从 2008 年的 11 个增加到 2017 年 17 个, 而中级及良好协调地区从 2008 年 1 个增加 到 2017 年 14 个。总体来说, 美丽中国建设系统间耦合协调发展程度, 随时间的增加逐渐变好, 但在 2017 年 时仍有近 55\%的省市处于基本协调及初级协调类型, 其中宁、晋、黔、新、冀、青、藏为基本协调, 主要集中在西 部地区,该地社会、经济发展落后, 经济发展模式单一, 易受自然灾害影响,而秦、豫、湘、云、桂、甘、内蒙古、琼、 津、吉等初级协调类型大部分为中部地区, 该类型区域的社会、经济需要依赖东部地区的带动发展, 同时因毗 邻东部地区人才外流严重。 


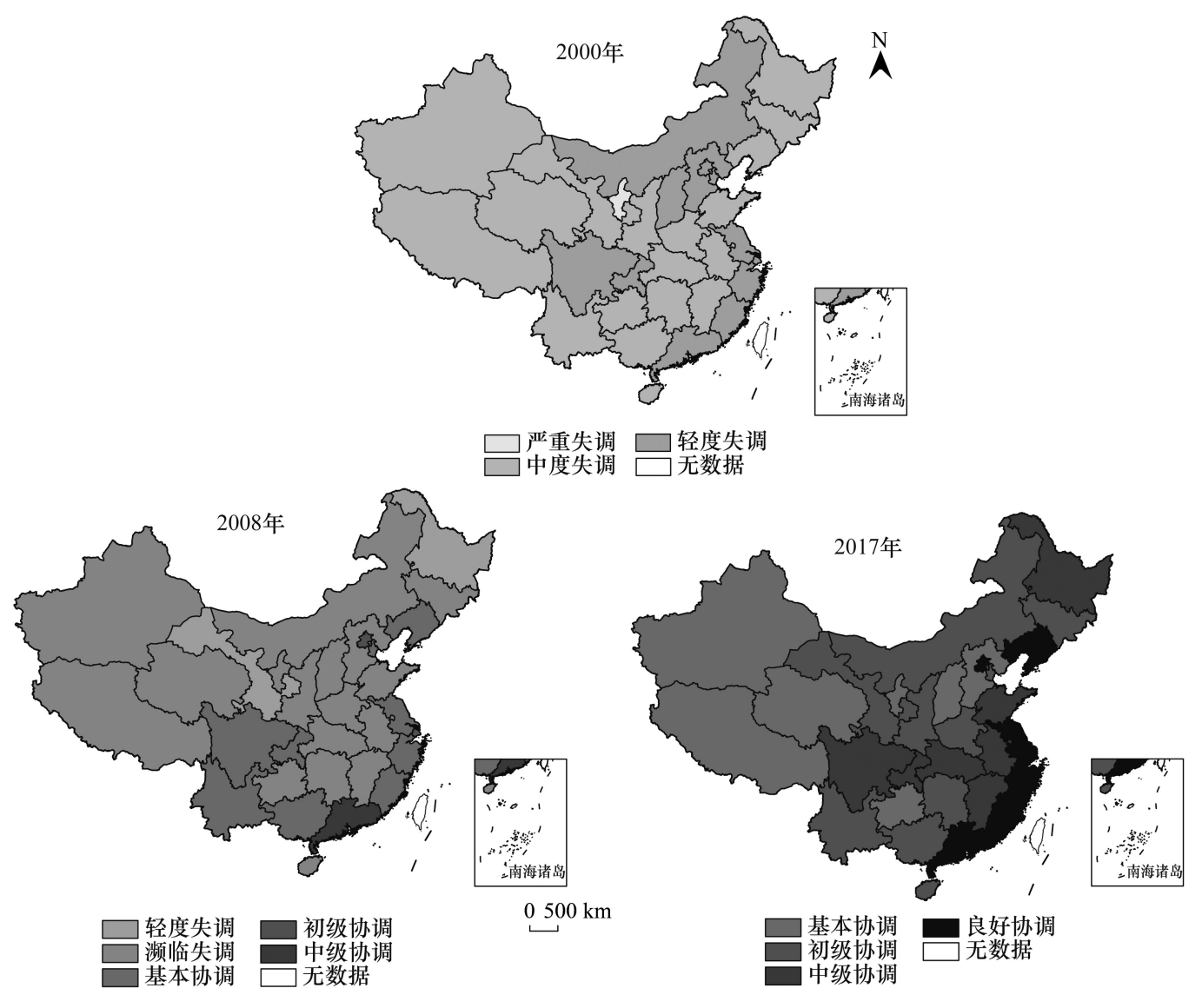

图 7 我国各省市美丽中国建设静态耦合协调度

Fig.7 Static coupling co scheduling of Beautiful China construction in provinces and cities of China

从耦合协调空间特征来看, 区域间发展差异明显。2000 年,由于仅注重经济、社会发展,忽略了文化及制 度的建设, 导致系统发展失衡, 大部分地区处于中度失调, 到 2008 年, 我国系统耦合协调程度由东南地区向西 北地区, 从协调转变为失调, 即我国东南大部分地区达到协调程度, 但西部大部分地区仍处于失调状态, 在 2017 年时,随着《大气污染治理法》、经济高质量发展等政策的提出,我国美丽中国建设的系统间发展趋于协 调, 地区发展失调的状况逐渐得到改善,协调程度较高的地区向东部地区收缩, 并呈现 “ $\mathrm{T}$ ” 型分布, 以东部地 区为良好协调地区, 鄂、鲁、渝、赣、晥、川为中级协调地区。由此可知, 美丽中国系统协调程度较好的地区以东 部为主,东部地区拥有明显的区位优势,21 世纪初提出的对外开放政策使当地经济迅速发展,年均 GDP 增长 率达到 $13.1 \%$, 吸引了大量科研人才, 同时东部地区的社会发展程度高,城市基础设施完善,教育医疗水平发 达, 高素质教育也为其提供了丰富的人才资源。而西部地区大多数省市耦合协调程度较差,一方面是东部地 区在带动西部发展时, 分配的资源比较分散,存在注重城市发展,轻视农村的行为, 且未能及时促进当地产业 结构转型, 因此效果有限; 另一方面,西部地区自身美丽中国的发展存在诸多不足,地处相对封闭或半封闭地 带, 部分区域气候条件恶劣, 使得经济发展较东部地区相对落后, 虽然拥有独特的西部民族文化, 但其美丽中 国建设系统间协调程度较差。

2000-2017 年间,大多数地区协调水平变化幅度大致相同,但也存在一些协调水平跨越幅度不同于普通 地区的特殊地区,大致可分为两类:一类是耦合协调水平转变较大的地区,如浙、闽、黑。浙江及福建省的协调 水平均由轻度失调升至基本协调最终完成向良好协调的转变,其中浙江省在研究期内实现了从计划经济向实 体经济的转变,截止 2017 年,该地民营企业占全省 65\%的 GDP,54\%的税收及 $80 \%$ 的就业岗位,极大程度地促 进了当地经济、社会的发展,而福建的人均 GDP 在研究期内翻了 7 倍,森林覆盖率全国第一,达到 $66.8 \%$,黑 
龙江省完成了由中度失调到濒临失调最终向中级协调的转变, 由上文可知, 黑龙江省加强了系统间协同发展 的程度, 因此其协调水平跨越幅度较大。另一类是耦合类型水平转变较小的地区, 如鄂、晋、新、藏、青等地。 以河北和山西为例, 河北的协调水平转变缓慢, 仅从轻度失调转变为基本协调, 究其原因河北省虽为沿海省, 但仅有唐山及秦皇岛靠海, 海上外贸经济发展不顺, 毗邻天津和北京但未受到两地的陆域经济辐射, 因此经济 发展缓慢, 人才流失严重, 同时河北省水资源拥有量远不及全国平均水平, 属于缺乏严重地区; 山西省是我国 煤炭能源基地,但因非法违法开采、资源节约等问题,山西省实行关闭煤矿的政策,但因处理方式及资源利用 等方面不够重视, 部分关闭的煤矿出现区域地表水污染现象 ${ }^{[40]}$, 这使得山西省水资源缺乏的形式更加严峻, 同时关闭煤矿造成山西省经济发展速度减缓,在 2015 年时出现了经济负增长。

\section{2 动态耦合协调}

由于静态耦合协调仅能看出发展过程中的现状,但 美丽中国的发展是一个动态演变过程,需要考虑观察期 内系统间动态变化的方向及大小,因此判断我国美丽中 国建设系统动态耦合协调水平,需要两个基本分析过 程:一是识别系统间发展方向是否一致,二是分析系统 间发展速率是否协调 ${ }^{[41]}$ 。根据公式 6-7 可以获取我 国美丽中国建设动态耦合的空间特征,如图 8 所示。为 了简洁描述, 现将耦合度 $<0$ 定义为负向耦合阶段、00.3 定义为低水平耦合阶段、 $0.3-0.5$ 定义为拮抗阶段、 $0.5-0.8$ 定义为磨合阶段、 $0.8-1$ 定义为高水平耦合 阶段。

研究表明, 2000-2017 年间我国美丽中国建设动 态耦合水平明显低于静态耦合,我国省市并未出现社 会、环境、经济、文化以及制度四种及以上的系统同时负

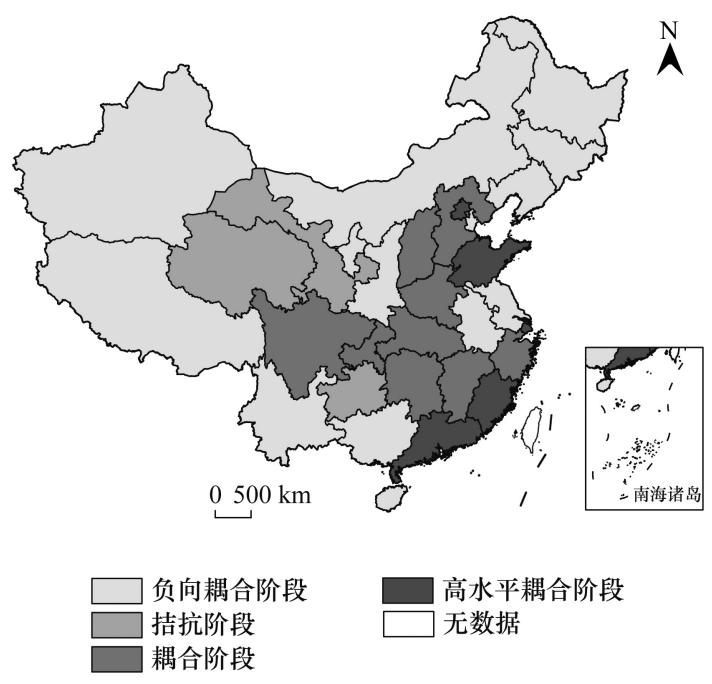

图 8 我国的美丽中国建设动态耦合图

Fig.8 Dynamic coupling of Beautiful China construction 向增长,处于负向耦合、拮抗阶段、磨合阶段和高水平耦 合的省市数量分别为 12 个(云、黑、藏、琼、辽、津、晥、苏、秦、内蒙古、新、宁)、4 个(桂、黔、甘、青)、10 个(晋、 赣、豫、湘、浙、鄂、川、渝、冀、吉) 和 5 个(沪、京、粤、闽、鲁) ; 部分省市如山西和四川省出现了并未预期的高水 平动态耦合状态。从图中可以看出, 我国大部分省市仍处于负向耦合状态以及磨合阶段,负向耦合状态集中 体现在我国中部地区, 而高水平及磨合阶段的动态耦合较多聚集于东南沿海地区,这充分体现了我国东南部 地区美丽中国建设发展程度较高, 中部地区在美丽中国建设过程中会出现发展受阻的情况。

需要说明的是 2000-2017 年,在我国美丽中国建设发展过程中共有 16 个省市存在社会、环境、经济、文 化、制度发展方向不一致的情况,其中 12 个省市为负向耦合,但有 4 个省市 (鄂、晋、黔、青)在正向耦合中, 表 明这些省市的某一或某些系统在发展中遇到瓶颈, 大致可分为四类: (1)青、新为社会发展受阻型省份, 以青海 为例, 青海省位于我国西部, 其海拔高且气象灾害较多, 而人类活动的基础就是自然环境, 它较大程度的限制 着社会的进步,因此青海省的人口密度从 2000-2017 年几乎未变,仅从 7 人 $/ \mathrm{km}^{2}$ 增加到 8 人 $/ \mathrm{km}^{2}$ 。(2)津、鄂、 晋、晥、吉、苏、桂、宁、新、云、秦为绿色环境发展受阻,这也是美丽中国建设发展中存在的普遍现象, 即以牺牲 环境为代价发展经济建设, 有统计显示在《斯德哥尔摩公约》中明确禁止的 12 种持久性有机污染物, 在我国 的环境介质中多有检出, 而这类污染物多出现于第一、第二产业中。3辽、黑、鄂、晋、琼、内蒙古、藏、甘、青、新 为经济发展受阻型省份, 其中青海以及新疆的经济发展受环境及社会制约,藏、甘、辽、黑、鄂、晋受环境和资源 可持续发展的约束, 而内蒙古的经济下滑不明显,近乎持平, 内蒙古主要靠二三产业发展, 但其区域内发展不 协调, 资源、投资分布不均衡, 产业结构及科研力量存在差异, 因此出现经济发展受阻现象。(4)津、桂、黔、宁四 个省市是由文化和制度发展程度降低所引起的美丽中国建设发展受阻的省份, 说明该类型地区在美丽中国建 
设发展过程中并未注重文化以及制度的建设,尤其是宁夏,其政府信息公开度远不及全国平均水平的 $1 / 5$ 。

\section{4 结论}

本文以我国 31 个省、市、自治区为研究区域,2000-2017 年为研究时段,基于空间自相关及动静态耦合 模型, 研究我国美丽中国建设的时空分异规律、分布格局及耦合协调度, 研究表明:

(1) 研究期内, 我国美丽中国建设总体呈波动上升, 从 2000 年的 12.51 上升至 2017 年的 14.02 , 速度由快 到慢并趋于平稳; 研究区内, 呈东部地区>西部地区>中部地区的分布规律。

(2) 我国美丽中国建设整体呈显著的正向空间关联,发展格局稳定,但两极化问题严重,中西部地区发展 落后, 东南沿海以及西部边界地区发展程度较好, 且随着时间增长, 有向中部地区扩散的趋势, 其中黑龙江完 成了从低值区向高值区的转变, 天津则从高值区转向了低值区; 子系统中, 除制度体系不显著外, 其余系统均 存在正向空间关联,且我国东部地区尤其是东南地区的社会、经济、文化发展程度高, 中西部地区的环境发展 相对较好。

(3) 我国美丽中国建设系统的静态耦合协调度, 从 2000 年到 2017 年处于波动上升趋势, 协调等级从濒临 失调最终达到中级协调, 系统协调程度东部高于西部地区, 区域间发展差异明显; 动态耦合度体现出子系统发 展水平及方向不一致性, 其中共有 16 个省市存在社会发展受阻、绿色环境受阻、经济增长受阻、以及文化和制 度发展受阻的情况, 总体而言, 我国美丽中国建设发展协调关系趋于完善, 但动态耦合不及静态耦合协调 水平。

美丽中国作为一个复杂的系统工程, 其相关研究起步较晚, 仍有许多学术问题值得讨论。在评价美丽中 国建设时空变化规律时, 不仅要重视宏观和中观尺度,还要重视微观尺度下的美丽中国建设,探讨和人生活密 切相关的 “美丽城市” “美丽乡村” “美丽社区” 建设。在对美丽中国系统协调度的测评时, 忽视了政策实施的 滞后性及环境治理的时间滞后,这些问题在不同程度上会对各地的美丽中国系统耦合度的计算结果存在影 响,未来需将这些问题考虑进去以消除计算误差。另外本文评价分析了美丽中国时空分布格局以及系统协调 性,但对于格局形成的驱动因素以及美丽中国的未来发展预测仍有待深人研究。

\section{参考文献 (References) :}

[ 1 ] 秦书生, 胡楠. 美丽中国建设的内涵分析与实践要求——关于习近平美丽中国建设重要论述的思辨. 环境保护, 2018, 46(10): 9- 12.

[ 2 ] 中国共产党新闻网. 十八大报告中“美丽中国”成为各界关注新词. [2012-11-13]. http://news. sina.com.cn/c/2012-11-13/082825568054. shtml.

[ 3 ] 万俊人. 美丽中国的哲学智慧与行动意义. 中国社会科学, 2013, (5) : 5-11.

[4] 许瑛. “美丽中国”的内涵、制约因素及实现途径. 理论界, 2013, (1): 62-64.

[ 5 ] 李建华, 蔡尚伟. “美丽中国”的科学内涵及其战略意义. 四川大学学报: 哲学社会科学版, 2013, (5): 135-140.

[ 6 ] 陈明星, 梁龙武, 王振波, 张文忠, 余建辉, 梁宜. 美丽中国与国土空间规划关系的地理学思考. 地理学报, 2019, 74(12): 2467-2481.

[ 7 ] Marinelli M. How to build a 'beautiful China' in the anthropocene. The political discourse and the intellectual debate on ecological civilization. Journal of Chinese Political Science, 2018, 23(3) : 365-386.

[ 8 ] Sauvé S, Bernard S, Sloan P. Environmental sciences, sustainable development and circular economy: alternative concepts for trans-disciplinary research. Environmental Development, 2016, 17: 48-56.

[ 9 ] Strezov V, Evans A, Evans T J. Assessment of the economic, social and environmental dimensions of the indicators for sustainable development. Sustainable Development, 2017, 25(3) : 242-253.

[10] 时朋飞, 熊元斌, 邓志伟, 李文杰, 李星明. 长江经济带 “美丽中国” 建设水平动态研究一一基于生态位理论视角. 资源开发与市场, 2017, 33(11): 1317-1323, 1395-1395.

[11］向云波, 谢炳庚. "美丽中国" 区域建设评价指标体系设计. 统计与决策, 2015, (5): 51-55.

[12］方创琳, 王振波, 刘海猛. 美丽中国建设的理论基础与评估方案探索. 地理学报, 2019, 74(4): 619-632.

[13] 高卿, 骆华松, 王振波, 宋金平.美丽中国的研究进展及展望. 地理科学进展, 2019, 38(7): 1021-1033.

[14] 夏赞才, 张苏兰, 李典友, 薛中俊, 邹泉. 美丽中国建设和区域旅游化耦合协调研究一一以丝绸之路经济带中国段为例. 资源开发与市 
场, 2019, 35(5): 724-728.

[15] 时朋飞, 李星明, 熊元斌. 区域美丽中国建设与旅游业发展耦合关联性测度及前景预测——以长江经济带 11 省市为例. 中国软科学, 2018, (2) : 86- 102 .

[16] 潘苏楠, 李北伟, 聂洪光. 新能源汽车产业与美丽中国建设的耦合协调及前景预测研究. 科技管理研究, 2019, 39(18): 123-129.

［17］潘苏楠，李北伟，聂洪光. 科技创新与美丽中国建设的协调发展一一基于系统耦合视角. 技术经济, 2019，38(3)：60-66.

［18］谢炳庚, 陈永林, 李晓青. 耦合协调模型在"美丽中国"建设评价中的运用. 经济地理, 2016, 36(7) : 38-44.

［19］陆树程, 李佳娟. 试析习近平美丽中国思想的提出语境、主要内容和基本要求. 思想理论教育导刊, 2018, (9) : 29-34.

[20] 曾鹏. 绿色发展理念视國下美丽中国建设研究 [D]. 武汉:武汉大学. 2017: 26-67.

[21] 傅丽华, 李晓青, 凌纯. 基于景观敏感性视角的"美丽中国"评价指标权重分析. 湖南师范大学自然科学学报, 2014, 37(1): 1-5.

[22] 陈军绘. "美丽中国" 视域下大学生生态文明意识培育. 广东省社会主义学院学报, 2014, (1) : 96-99.

[23] 万军, 王倩, 李新, 秦昌波. 基于美丽中国的生态环境保护战略初步研究. 环境保护, 2018, 46(22): 7-11.

[24] 刘笑菊. "美丽中国"建设语境下当代大学生生态素养培育探析——基于中国传统生态文化传承的视角. 学校党建与思想教育, 2019, (2) : 32-34.

[25] 高峰, 赵雪雁, 宋晓谕, 王宝, 王鹏龙, 牛艺博, 王伟军, 黄春林. 面向 SDGs 的美丽中国内涵与评价指标体系. 地球科学进展, 2019, 34 (3) : 295-305.

[26] 谢炳庚, 陈永林, 李晓青. 基于生态位理论的"美丽中国"评价体系. 经济地理, 2015, 35(12): 36-42.

[27］国家统计局，国家环境保护总局. 中国环境统计年鉴. 北京: 中国统计出版社, 2006.

[28] 中国环境报社. 中国环境年鉴. 北京: 中国环境年鉴编辑部, 2015 .

[29］中国法律年鉴编辑部. 中国法律年鉴. 北京: 中国法律年鉴社出版, 2000.

[30] 最高人民检察院《中国检察年鉴》编辑部. 2005 中国检察年鉴. 北京: 中国检察出版社, 2006.

［31］李国兵, 田亚平. 珠三角旅游资源竞争力与旅游业发展水平的效度分析. 经济地理, 2019, 39(3): 218-224, 239- 239.

[32] 王新越, 朱文亮. 山东省乡村旅游竞争力评价与障碍因素分析. 地理科学, 2019, 39(1): 147-155.

[33] 刘鹏, 王莉芳, 许燕. 基于“专家打分法”的 DEA 交叉效率聚集方法. 科技管理研究, 2019, 39(2): 248-253.

[34] 任平, 洪步庭, 周介铭. 基于空间自相关模型的农村居民点时空演变格局与特征研究. 长江流域资源与环境, 2015, 24(12)：1993-2002.

[35] 范建双, 周琳. 中国建筑业碳排放时空特征及分省贡献. 资源科学, 2019, 41(5)：897-907.

[36] 倪印锋, 王明利. 中国牧草产业地理集聚特征及影响因素. 经济地理, 2018, 38(6): 142-150.

[37] 刘浩, 张毅, 郑文升. 城市土地集约利用与区域城市化的时空耦合协调发展评价一一以环渤海地区城市为例. 地理研究, 2011, 30(10): 1805-1817.

［38］廖重斌. 环境与经济协调发展的定量评判及其分类体系——以珠江三角洲城市群为例. 热带地理, 1999, 19(2): 171- 177.

[39］丛小丽, 黄悦, 刘继生. 吉林省生态旅游与旅游环境耦合协调度的时空演化研究. 地理科学, 2019, 39(3): 496-505.

[40] 刘汉斌, 张亚宁, 程芳琴. 山西关闭煤矿资源利用现状及开发利用建议. 煤炭经济研究, 2019, 39(10): 78-82.

[41] 孔雪松, 谢世姣, 朱思阳, 何义国, 银超慧. 湖北省人口一土地一产业城镇化的时空分异与动态耦合分析. 经济地理, 2019, 39(4)： 93-100. 